\title{
Analisis Kesulitan Belajar Pendidikan Agama Islam (PAI) \\ Serta Cara Mengatasinya
}

\author{
Siti Nusroh \\ wafeqdiana@gmail.com \\ Institut Agama Islam Negeri (IAIN) Kudus \\ Eva Luthfi Fakhru Ahsani \\ evaluthfi@iainkudus.ac.id \\ Institut Agama Islam Negeri (IAIN) Kudus
}

\begin{abstract}
Abstrac: Difficulty of student learning is an obstacle experienced by students in their efforts to learn the subjects they learn in school, or things that can lead to failure of learning progress. Teachers play an important role in terms of helping students overcome learning difficulties, improving student achievement and learning outcomes, as a teacher's teaching reference so that it is better to be material for students in facing and overcoming student learning difficulties, and for schools contributing important information that is good for schools in order improvement of the teaching and learning process of Islamic Religious Education. How to overcome the results of this article are obtained that the results show that: (1) Choosing the PAI learning method appropriately, so students do not get bored and bored with PAI subjects, especially reading and memorizing the Qur'an. (2) The use of varied media both originates from print media, electronics and so on to support the learning process. (3) Always provide motivation to students after completing learning activities and strengthen the spirit in their souls so that the student is happy with the teacher and his brain becomes easy to accept the lesson.
\end{abstract}

Keywords: Learning Difficulties, Islamic Religious Education

Abstrak: Kesulitan belajar siswa merupakan hambatan yang dialami peserta didik dalam usahanya mempelajari mata pelajaran yang dipelajarinya di sekolah, atau hal-hal yang dapat mengakibatkan kegagalan kemajuan belajarnya. Guru berperan penting dalam hal membantu siswa mengatasi kesulitan belajar, meningkatkan prestasi dan hasil belajar siswa,

Belajea: Jurnal Pendidikan Islam Vol. 5, No 01, 2020; 157-164 p-ISSN 2548-3390; e-ISSN 2548-3404, DOI:10.29240/belajea.v4i2.891 available online at:http://journal.staincurup.ac.id/indek.php/belajea 
72 | Belajea: Jurnal Pendidikan Islam, Vol. 5, No. 01, 2020

sebagai acuan guru mengajar supaya lebih baik menjadi bahan bagi peserta didik dalam menghadapi dan mengatasi kesulitan belajar siswa, dan bagi sekolah sumbangan informasi penting yang baik bagi sekolah dalam rangka perbaikan proses belajar mengajar Pendidikan Agama Islam. Cara mengatasi Hasil artikel ini diperoleh bahwa hasil menunjukan bahwa : (1)Memilih metode pembelajaran PAI secara tepat, sehingga siswa tidak bosan dan jenuh terhadap mata pelajaran PAI khususnya membaca dan menghafal AL-Qur'an. (2) Pengunaan media yang bervariasi baik itu bersumber dari media cetak, elektronik dan sebagainya guna menunjang proses pembelajaran. (3) Selalu memberikan motivasi kepada siswanya setelah selesai kegiatan pembelajaran dan memperkuat semangat di jiwanya sehingga siswa tersebut senang dengan guru tersebut dan otaknya menjadi mudah menerima pelajaran.

Kata Kunci : Kesulitan Belajar, Pendidikan Agama Islam

\section{Pendahuluan}

Belajar adalah suatu kegiatan yang dijalankan secara sadar, sengaja, teratur dan terencana guna mengubah dan mengembangkan kualitas manusia di dalam suatu sekolah. Sekolah adalah lembaga formal yang menjadi sarana pencapaian tujuan tersebut. Melalui sekolah, siswa dapat belajar berbagai macam mata pelajaran. Baik ilmu pengetahuan maupun ketrampilan karena berhasil tidaknya pencapaian tujuan pendidikan banyak bergantung pada proses belajar yang dialami oleh siswa. Dalam proses belajar mengajar di sekolah, setiap guru senantiasa mengharapkan agar anak didiknya dapat mencapai hasil belajar yang sebaik-baiknya. Dalam kenyataannya banyak siswa yang menunjukkan tidak dapat mencapai hasil belajar sebagaimana yang diharapkan. Beberapa siswa masih menunjukkan nilai-nilai yang rendah meskipun telah diusahakan dengan sebaik-baiknya oleh guru. Dengan kata lain, mengalami kesulitan belajar. Setiap anak atau siswa memiliki sesuatu yang membedakannya dengan orang lain, dan setiap orang mempunyai karakteristik sendiri-sendiri. Setiap anak atau siswa memiliki perbedaan, baik pada aspek fisik, emosional,intelektual, sosial, lingkungan dan tingkat ekonomi yang berbeda-beda. Hal itu dapat menjadi faktor penyebab sulitnya siswa dalam belajar. Masing-masing faktor saling terkait dan tidak dapat berdiri sendiri dalam mempengaruhi prestasi belajar. 
Proses belajar mengajar merupakan kegiatan untuk membentuk perubahan tingkah laku dalam diri siswa di dalam mencapai tujuan Pendidikan Agama Islam. Dalam proses kegiatan belajar mengajar Pendidikan Agama Islam sering dijumpai berbagai permasalahan yang menjadi kendala belajar yang disebabkan adanya keanekaragaman kemampuan dan karakteristik gaya belajar sehingga tingkat penguasaan belajar berbeda antara siswa satu dengan yang lainnya ${ }^{1}$

Prestasi belajar merupakan tolak ukur yang mudah dikontrol untuk menentukan berhasil atau tidaknya proses pembelajaran. Fakta ini menunjukkan ada masalah yang dihadapi oleh siswa dalam belajarnya. Setiap siswa pernah mengalami kesulitan belajar meskipun dalam tingkat yang berbeda-beda. Keadaan seperti di atas sering dialami oleh lembaga pendidikan di berbagai jenjang memperoleh prestasi belajar di bawah rata-rata. Ini menunjukan adanya kesulitan belajar siswa yang mempengaruhi prestasi belajar. Untuk itu harus ada penanganan terhadap kesulitan belajar yang dialami siswa yakni dengan mendiagnosis dan solusi dari kesulitan belajar yang dialami siswa dan cara mengatasinya. Dalam mengajar peserta didik adalah sebagai subjek dan sebagai objek dari kegiatan pengajaran karena inti proses belajar anak didik dalam mencapai prestasi belajar merupakan tolak ukur yang mudah dikontrol untuk menentukan berhasil atau tidaknya proses pembelajaran. Kesulitan belajar merupakan suatu gejala yang selalu dihadapi oleh guru, karena guru bertanggung jawab untuk mengatasinya Hampir di setiap sekolah ditemukan siswa yang mengalami kesulitan dalam belajar ${ }^{2}$.

Fakta ini menunjukkan ada masalah yang dihadapi oleh siswa dalam belajarnya. Setiap siswa pernah mengalami kesulitan belajar meskipun dalam tingkat yang berbeda-beda. Keadaan seperti di atas sering dialami oleh lembaga pendidikan di berbagai jenjang memperoleh prestasi belajar di bawah rata-rata. Ini menunjukan adanya kesulitan belajar siswa yang mempengaruhi prestasi belajar. Untuk itu harus ada penanganan terhadap kesulitan belajar yang dialami

${ }^{1}$ Muntari. 2015. Upaya Guru Mengatasi Kesulitan Belajar Siswa Bidang Studi Pendidikan Agama Islam Di SD Mujahidin 2 Surabaya . Tarus: Jurnal Pendidikan Islam. 4 (1): $1-16$

${ }^{2}$ Munirah. 2018. Peranan Guru dalam Mengatasi Kesulitan Belajar Siswa. Tarbawi: Jurnal Pendidikan Agama Ilsam. 3(2): 111-127 
siswa yakni dengan mendiagnosis dan solusi dari kesulitan belajar yang dialami siswa dan cara mengatasinya. Dalam mengajar peserta didik adalah sebagai subjek dan sebagai objek dari kegiatan pengajaran karena inti proses belajar anak didik dalam mencapai suatu tujuan pengajaran. Tujuan pengajaran tentu saja akan dapat dicapai anak- anak didik berusaha secara aktif untuk mencapainya. Keaktifan peserta didik disini tidak hanya dituntut dari segi fisik, tetapi juga dari segi kejiwaan. Bila hanya fisik yang aktif, tetapi pikiran dan mentalnya kurang aktif, maka kemungkinan besar tujuan pembelajaran tidak tercapai. Ini sama ha ${ }^{3}$ Inya peserta didik tidak belajar, karna peserta didik tidak merasakan perubahan di dalam dirinya. Biasanya, permasalahan yang guru hadapi ketika berhadapan dengan sejumlah peserta didik adalah masalah pengengolaan kelas. Apa, siapa, bagaimana, kapan, dan di mana adalah pertanyaan yang perlu dijawab dalam hubungannya dengan masalah pengelolaan kelas, peranan guru itu tidak berusaha mengatur suasana kelas yang kondusif bagi kegairahan dituntut untuk mengelola kelas sehingga berakhirnya kegiatan pembelajaraan. Jadi, masalah pengaturan kelas ini tidak akan pernah sepi dari kegiatan guru.

Semua kegiatan itu guru dilakukan demi kepentingan peserta didik, demi keberhasilan belajar anak didik kelas sehingga berakhirnya kegiatan belajar mengajar. Guru turut berperan membantu memecahkan masalah yang dihadapi siswa, peran guru sangat diperlukan oleh peserta didik. Adapaun tipe belajar peserta didik Yaitu: Pertama, ada peserta didik yang cepat mencerna bahan. Setiap peserta didik mempunyai keragaman dalam hal kecakapan maupun kepribadian, Kecakapan yang dimiliki masing-masing peserta didik itu meliputi kecakapan potensial yang kemungkinan dan dikembangkan, seperti bakat dan kecerdasan maupun kecakapan yang diperoleh dari hasil belajar. Kedua, ada peserta didik sedang dalam merencanakan bahan yang diberikan oleh guru. Peserta didik yang diajar di kelas pada dasarnya sedang dalam proses perkembangan yang akan terus berkembang. Sehubung dengan perkembangan ini maka kemampuan peserta didik pada setiap jenjang usia dan pada tingkat kelas juga akan berbeda-berbeda.

Berdasarkan hal tersebut maka seorang guru dalam memilih bahan dan metode pembelajaran harus disesuaikan dengan kemampuan peserta didik

${ }^{3}$ Ismail. 2016. Diagnosis Kesulitan Belajar Siswa dalam Pembelajaran Aktif di Sekolah. Jurnal Edukasi. 2 (1): 30-43 
tersebut. Ketiga, ada peserta didik lambat menerima materi yang diajarkan oleh guru. Guru akan mempunyai pengalaman dalam pembelajaran tentang peserta didik di kelas yang lambat menerima pembelajaran. Apabila dalam pembelajaran ini seorang guru tidak sabar dalam mengelola pembelajaran. Dalam pembelajaran pada peserta didik yang berusaha secara aktif untuk mencapainya. Keaktifan peserta didik disini tidak hanya dituntut dari segi fisik, tetapi juga dari segi kejiwaan. Bila hanya fisik yang aktif, tetapi pikiran dan mentalnya kurang aktif, maka kemungkinan besar tujuan pembelajaran tidak tercapai. Ini sama halnya peserta didik tidak belajar, karna peserta didik tidak merasakan perubahan di dalam dirinya. Biasanya, permasalahan yang guru hadapi ketika berhadapan dengan sejumlah peserta didik adalah masalah pengengolaan kelas. Apa, siapa, bagaimana, kapan, dan di mana adalah pertanyaan yang perlu dijawab dalam hubungannya dengan masalah pengelolaan kelas, peranan guru itu tidak berusaha mengatur suasana kelas yang kondusif bagi kegairahan dituntut untuk mengelola kelas sehingga berakhirnya kegiatan pembelajaraan. Jadi, masalah pengaturan kelas ini tidak akan pernah sepi dari kegiatan guru.

\section{Pembahasan}

Belajar adalah merupakan proses dasar dari perkembangan hidup manusia. Dengan belajar, manusia melakukan perubahan-perubahan tingkah lakunya berkembang ${ }^{4}$. Sedangkan Imam Bawani, menyatakan belajar adalah bimbingan jasmani-rohani hukum-hukum Islam menuju kepada terbentuknya kepribadian utama menurut ukuran-ukuran Islam ${ }^{5}$. Belajar adalah proses internalisasi atau penyerapan kecakapan (kognitif, afektif, maupun psikomotorik) ke dalam diri yang bersumber dari pengalaman-pengalaman dan latihan melalui usaha. Bentuk-bentuk usaha tersebut dapat berupa aktivitas yang mengarah pada tercapainya perubahan pada diri seseorang banyak sekali. Pendidikan adalah usaha sadar dan bertujuan untuk mengembangkan kualitas manusia sebagai suatu kegiatan sadar akan tujuan. Maka, dalam pelaksanaanya berada dalam suatu proses yang berkesinambungan dalam setiap jenis dan jenjang pendidikan,

\footnotetext{
${ }^{4}$ Nidawati. 2013. Belajar dalam Perspektif Psikologi dan Agama. 1(1): 13-28

5 An-Nahlawi, Abdurrahman, Ushulut Tarbiyatil Ilmiyah wa Asalibuha, Ter. Hery Noer Aly (Bandung: CV. Diponegoro, 1989), hal. 9
} 
76 | Belajea: Jurnal Pendidikan Islam, Vol. 5, No. 01, 2020

semuanya berkaitan dalam suatu sistem pendidikan, semuanya berkaitan dalam suatu sistem pendidikan yang integral.

Belajar dan pembelajaran adalah dua hal yang saling berhubungan erat dan tidak dapat dipisahkan dalam kegiatan edukatif ${ }^{6}$. Dalam kegiatan pembelajaran di sekolah, para pendidik dihadapkan dengan sejumlah karakteristik siswa yang beraneka ragam dan berbeda beda. Ada siswa yang dapat menempuh kegiatan belajarnya secara efektif, efesien serta lancar dan berhasil tanpa mengalami kesulitan, kesulitan belajar siswa ditunjukan oleh adanya hambatan-hambatan tertentu untuk mencapai hasil belajar, dan dapat bersifat psikologis,sosiologis,maupun fisiologis,sehingga pada akhirnya dapat menyebabkan prestasi belajar yang dicapainya berada di bawah semestinya. Banyak di antara siswa yang tidak dapat mengembangkan pemahamanya terhadap konsep Pendidikan Agama Islam (PAI) tertentu karena antara perolehan pengetahuan dengan prosesnya tidak terintegrasi dengan baik dan tidak memungkinkan siswa untuk menerima materi secara fleksibel. Kesulitan belajar merupakan terjemahan istilah bahasa inggris learning disability. Terjemahan tersebut, sesungguhnya kurang tepat karena learning artinya belajar dan disability artinya ketidakmampuan, sehingga terjemahan yang benar seharusnya adalah ketidakmampuan belajar.

Kesulitan belajar di sekolah bermacam-macam,yang berdasarkan hal sumber kesulitan dalam proses belajar,baik dalam hal menerima pelajaran atau dalam menyerap pelajaran. Dengan demikian, pengertian kesulitan belajar di sini dapat diartikan sebagai kesukaran siswa dalam menerima atau menyerap pelajaran disekolah. Jadi, kesulitan belajar yang dihadapi siswa terjadi pada waktu mengikuti pelajaran yang disampaikan atau di tugaskan oleh seorang guru. Hal tersebut dapat kita lihat dari nilai atau presentasi yang mereka peroleh. Siswa yang mengalami kesulitan dalam belajar akan memperoleh nilai yang kurang memuaskan dibandingkan siswa lainya. Menurut pendapat saya "Fenomena kesulitan belajar seorang siswa biasanya terlihat jelas dari menurunya kinerja akademik atau prestasi belajarnya". Kesulitan belajar siswa mencakup pengertian yang luas, diantaranya :

\footnotetext{
${ }^{6}$ Pane, Aprida. 2017. Belajar dan Pembelajaran. Jurnal Kajian Ilmu-Ilmu Keislaman.
} $3(2): 333-352$ 
1. Learning Disorder atau kekacauan belajar adalah keadaan dimana proses belajar seseorang terggangu karena timbulnya respons yang bertentangan. Pada dasarnya yang mengalami kekacauan belajar, potensinya tidak dirugikan, akan tetapi belajarnya terganggu atau terhambat oleh adanya respon-respon yang bertentangan, sehingga hasil belajar yang dicapainya lebih rendah dari potensi yang dimilikinya. Contoh: siswa yang sudah terbiasa dengan olah raga keras seperti karate, tinju dan sejenisnya, mungkin akan mengalami kesulitan dalam belajar menari yang menuntut gerakan lemah dan luwes.

2. Learning Disfunction merupakan gejala di mana proses belajar yang dilakukan siswa tidak berfungsi dengan baik, meskipun sebenarnya siswa tersebut tidak menunjukan subnormalitas mental, atau gangguan psikologisnya. Contoh: siswa yang memiliki postur tubuh yang ateletis dan sangat cocok menjadi atlet bulutangkis namun karena tidak pernah dilatih bermain bulutangkis. Maka dia tidak dapat menguasai permainan bulutangkis dengan baik.

3. Under Achiever mengacu kepada siswa yang sesungguhnnya memiliki tingkat potensi intelktual yang tergolong di atas normal, tetapi prestasi belajarnya tergolong rendah. Contoh: siswa yang sangat unggul (IQ = 130-150), namun prestasi belajarnya biasa-biasa saja atau malah sangat rendah.

4. Slow learner atau lambat belajar adalah siswa yang lambat dalam proses belajar, sehingga ia membutuhkan waktu yang lebih lama dibandingkan kelompok siswa lain yang memiliki taraf potensi intelektual yang sama.

5. Learning Disabilities atau ketidak mampuan belajar mengacu pada gejala dimana siswa tidak mampu belajar atau menghindari belajar, sehingga hasil belajar di bawah potensi intelektual.

Bila diamati, ada siswa yang mendapat kesulitan belajar dalam mencapai hasil belajar secara tuntas dengan variasi dua kelompok besar. Kelompok pertama merupakan sekelompok siswa yang belum mencapai tingkat ketuntasan, akan tetapi sudah hampir mencapainya. Siswa tersebut mendapat kesulitan dalam menetapkan penguasan bagian-bagian yang sulit dari seluruh bahan yang harus dipelajari. Kelompok yang kedua adalah sekelompok siswa yang belum mencapainya tingkat ketuntasan yang diharapkan karena ada konsep dasar yang 
belum dikuasai. Bisa pula ketuntasan belajar tak bisa dicapai kerana proses belajar yang sudah ditempuh tidak sesuai dengan karakteristik murid yang bersangkutan. Jenis dan tingkat kesulitan yang dialami oleh siswa tidak sama karena secara konseptual berbeda dalam memahami materi yang dipelajari secara menyeluruh dan mendalam. Pada dasarnya kesulitan belajar siswa merupakan suatu gejala yang nampak dalam berbagai manifestasi tingkah laku siswa, baik secara langsung maupun tidak langsung sesuai dengan tingkat kesulitan belajar siswa ${ }^{7}$. Kesulitan belajar siswa merupakan kondisi dimana anak dengan kemampuan intelegensi ratarata atau diatas rata-rata, namun memiliki ketidakmampuan dalam belajar yang berkaitan dengan hambatan dalam proses persepsi, konseptualisasi, berbahasa, memori, serta pemusatan perhatian, penguasaan $\operatorname{diri}^{8}$

Dari uraian di atas dapat diketahui bahwa siswa kesulitan belajar tidak hanya dialami oleh siswa yang berkemampuan kurang (di bawah rata-rata), akan tetapi juga dapat dialami oleh siswa yang berkemampuan rata-rata (normal) bahkan yang berkemampuan kinerja akademik yang sesuai dengan harapan. Perbedaan individual siswa merupakan salah satu penyebab kesulitan belajar dan proses belajar mengajar di sekolah. Faktor psikologi seperti perasaan tertekan yang disebabkan karena keadaan keluarga bisa saja menjadi penyebab seseorang mendapatkan hasil yang kurang baik dalam suatu tes bidang studi. Di samping itu, penyebab tidak baiknya nilai yang diperoleh siswa dari suatu mata pelajaran bisa jadi di karenakan ketidaksukaan siswa kepada gurunya atau cara gurunya mengajar. Bila nilai perolehan siswa umumnya atau semuanya jelek, ini kemungkinan besar karena rendahnya kemampuan siswa tersebut. Kesulitan adalah suatu hal yang berbeda di luar kekusaan manusia atau tidak dapat dihindari hanya dan tidak seoarang pun yang tidak menjumpainya di dalam kehidupan. Besar kecilnya kesulitan itu sangat relatif tergantung kepada individu yang mengalaminya. Kata kesulitan banyak dijumpai dalam berbagai bidang kegiatan dalam bidang pendidikan diistilahkan sebagai kesulitan belajar.

7 Muntari. 2015. Upaya Guru Mengatasi Kesulitan Belajar Siswa Bidang Studi Pendidikan Agama Islam Di SD Mujahidin 2 Surabaya . Tarus: Jurnal Pendidikan Islam. 4 (1): $1-16$

8 Suryani, Yulinda Erma. 2010. Kesulitan Belajar. Jurnal Penelitian Magistra. Magistra Th. XXII. No. 73: 33-47. 
Dapat di tarik kesimpulan Kesulitan belajar merupakan suatu masalah yang bersifat mendasari dan segera diatasi, kesulitan belajar dalam hal ini adalah hambatan-hambatan yang dialami peserta didik dalam usahanya mempelajari mata pelajaran yang dipelajarinya di sekolah, atau dengan kata lain: "hal-hal yang dapat mengakibatkan kegagalan atau menjadi gangguan yang dapat menghambat kemajuan belajarnya"

Jadi dalam hal ini kesulitan belajar ditekankan pada segi proses yaitu terjadinya beberapa hambatan yangdapat berpengaruh negatif terhadap proses belajar sehingga memberikan hasil yang tidak menguntungkan. Dengan demikian setelah diuraikan dari pengertian kesulitan belajar seperti terdahulu, maka dapat disimpulkan bahwa pengertian kesulitan belajar adalah usaha untuk mengetahui dan menentukan hambatan-hambatan yang menyebabkan peserta didik tidak berhasil mencapai presentasi yang baik dalam usaha belajar di sekolah dengan maksud mengadakan perbaikan.

\section{A. Gejala-Gejala Kesulitan Belajar}

Kegiatan belajar mengajar di dalam kelas yang dilakukan guru bersama murid akan menghasilkan kelompok yang cepat belajar dengan prestasi baik, kelompok murid yang sedang dengan prestasi dan kelompok murid yang lambat belajar dengan prestasi rendah. Hal ini biasanya menimbulkan reaksireaksi tertentu yang menimbulkan masalah dalam belajar. Kesulitan belajar tersebut dapat diagnosis dengan mengidentifikasi kasus, mengidentifikasi masalah dan mengidentifikasi penyebab kesulitan belajar?. Adapun gejala kesulitan belajar dapat dengan memperhatikan beberapa ciri-ciri tingkah laku yang merupakan manifestasi dari gejala kesulitan belajar, yaitu:

1. Menunjukan hasil belajar yang rendah (di bawah rata-rata nilai yang dicapai oleh kelompok belajar di kelas).

${ }^{9}$ Susanti, R. D. (2018). Strategi Guru Kelas Dalam Mengatasi Kesulitan Belajar Akademik Siswa Dalam Pembelajaran Di Sekolah Dasar. KONSELING EDUKASI Journal of Guidance and Counseling, 2(2): 139-154 
80 | Belajea: Jurnal Pendidikan Islam, Vol. 5, No. 01, 2020

2. Hasil yang dicapai tidak seimbang dengan usaha yang di lakukan, mungkin ada murid yang selalu berusaha untuk belajar dengan giat tetapi nilai yang dicapai kurang dan tidak sesuai dengan harapan.

3. Lambat dalam melakukan dan mengerjakan tugas-tugas kegiatan belajar. Ia selalu tertinggal dari kawan-kawannya dalam menyelesaikan tugastugas sesuai dengan waktu yang tersedia.

4. Memiliki atau menunjukkan sikap-sikap yang kurang wajar, menentang, berpura-pura, masa bodoh dan berdusta.

5. Menunjukkan tingkah laku yang menyimpang, seperti membolos, datang terlambat, tidak mengerjakan tugas, mengasingkan diri, tidak biasa bekerja sama, menggangu teman baik di luar maupun di dalam kelas, tidak mau mencatat pelajaran, tidak teratur belajar dan kurang percaya diri.

6. Menunjukkan gejala emosional yang kurang wajar yaitu pemarah,pemurung, mudah tersinggung, sensitif,tidak gembira dalam menghadapi situasi tertentu.

Belajar akademik mengarah pada adanya kegagalan-kegagalan dalam mencapai prestasi akademik yang sesuai dengan kapasitas yang diharapkan kegagalan tersebut mencakup penguasaan keterampilan dalam membaca, menulis ataupun matematika. Kesulitan ini dapat diketahui ketika siswa gagal menampilkan salah satu atau beberapa kemampuan akademik.Dari gejala-gejala yang tampak itu, guru bisa menginterprestasi bahwa ia kemungkinan mengalami kesulitan belajar. Disamping melihat gejala-gejala yang tampak, guru pun bisa mengadakan penyelidikan antara lain dengan: Observasi, cara memperoleh data dengan langsung mengamati terhadap objek. Kemudian diseleksi untuk dipilih yang sesuai dengan tujuan pendidikan. Data-data yang dapat diperoleh dengan observasi,misalnya:Bagaimana sikap siswa dalam mengikuti pelajaran, adalah tanda tanda cepat lelah, mudah mengantuk, sukar memusatkan perhatian pada pelajaran .

Kemungkinan bantuan jika letak kesulitan siswa sudah diketahui, baik jenis dan sifatnya dengan berbagai latar belakangnya maupun faktor-faktornya, maka guru akan memperkirakan: 1) Masih mungkinkah siswa ditolong. 2) Pertolongan apa yang harus diberikan. 3) Bagaimana cara memberi pertolongan yang efektif dan efisien, 4) Apa sarana dan fasilitas yang tepat untuk digunakan. 5) Siapa saja yang seharusnya terlibat dalam memberikan bantuan atau 
pertolongan dan apa perannya. Dengan demikian dalam proses pemecahan kesulitan belajar setelah letak kesulitan dipahami oleh guru, maka guru memperkirakan kemungkinan bantuannya. Yang antara lain mungkinkah siswa ditolong untuk mengatasi kesulitan belajarnya, siapa yang memberikan bantuan serta bagaimana memberi pertolongan yang efektif dan efisien sehingga kesulitan belajar yang dialami siswa dapat teratasi.

\section{B. Faktor Faktor Yang Mempengaruhi Kesulitan Belajar}

Faktor yang mempengaruhi kesulitan belajar itu ada berbagai macam, dapat di sadari bahwa belajar itu amat ditentukan oleh bagaimana proses belajar itu dilakukan. Secara global, faktor-faktor yang mempengaruhi belajar siswa dapat dibedakan menjadi dua bagian besar, yaitu: faktor yang berasal dari individu siswa yang belajar (faktor internal) merupakan faktor internal yang ada pada diri siswa itu adalah faktor yang kemampuan intelektual, faktor afektif seperti kebiasaan belajar, kemampuan mengingat, mendengar, perasaan, minat, motivasi, kematangan untuk belajar. Faktor yang berasal dari luar diri siswa (faktor exsternal). Sedangkan faktor eksternal yang ada di luar diri siswa adalah faktor-faktor yang berkaitan dengan kondisi belajar mengajar seperti guru, metode yang digunakan dalam belajar,kualitas proses belajar mengajar serta lingkungan seperti teman kelas, keluarga dan sebagainya. Sedangkan Selain ada faktor-faktor yang bersifat umum di atas, ada pula faktor-faktor lain yang juga menimbulkan kesulitan belajar siswa. Masing-masing faktor saling terkait dan tidak berdiri sendiri dalam mempengaruhi prestasi belajar ${ }^{10}$

Di antara faktor-faktor yang dapat dipandang sebagai faktor khusus ini ialah sindrom psikologi berupa learning disability (ketidakmampuan belajar). Sindrom (syndrome) yang berarti satuan gejala yang muncul sebagai indikator adanya ke apnormal psikis yang menimbulkan kesulitan belajar itu terdiri atas:

1. Disleksia (dyslexia), yakni ketidakmampuan belajar membaca.

2. Disgrafia (dysgraphia), yakni ketidakmampuan belajar menulis.

${ }^{10}$ Ixganda \& Suwahyo. 2015. Analisis Deskriptif Faktor Penyebab Kesulitan Belajar Pada Mata Pelajaran Chassis Dan Pemindah Daya Siswa Kelas Xi Program Keahlian Teknik Kendaraan Ringan. Jurnal Pendidikan Teknik Mesin. 15(2): 103-108 
82 | Belajea: Jurnal Pendidikan Islam, Vol. 5, No. 01, 2020

3. Diskalkukia (dyscalculia), yakni ketidakmampuan belajar matematika atau berhitung.

Namun demikian, siswa yang mengalami sindrom-sindrom di atas secara sistem sebenarnya memiliki potensi IQ yang normal, bahkan diantaranya ada yang memiliki kecerdasan di atas rata-rata. Oleh karena itu kesulitan belajar siswa yang menderita sindrom-sindrom tadi mungkin hanya disebabkan oleh adanya minimal brain dysfunction, yaitu gangguan ringan pada otak. Faktor-faktor di atas dalam banyak hal yang sering sekali berkaitan dan mempengaruhi satu sama lain. Seandainya seorang siswa yang bersikap conserving terhadap ilmu pengertahuan atau bermotif ekstrinsik (faktor eksternal),biasanya cenderung mengambil pendekatan belajar yang sederhana dan tidak mendalam. Secara garis besar, faktor-faktor penyebab timbulnya kesulitan belajar terdiri atas dua macam, yakni:

\section{Faktor intern siswa}

Faktor ini merupakan hal-hal atau keadaan-keadaan yang muncul dari dalam diri siswa sendiri. Faktor intern siswa ini meliputi gangguan atau kekurangmampuan psiko-fisik siswa, yakni:

a. Faktor Biologis

Faktor Biologis ialah faktor yang berhubungan denagan jasmani siswa. Faktor ini misalanya:

1) Kesehatan adalah faktor penting di dalam belajar. Karena keadaan siswa akan sangat berpengaruh terhadap efektifitas belajar, baik keadaan atau kebugaran jasmani. Dengan demikian keadaan jasmani siswa yang tidak memungkinkan untuk menerima pelajaran yang disebabkan karena sakit atau kurang sehat akan menghambat dalam belajar, karena orang yang sakit akan mengalami kelemahan fisiknya. Demikian halnya siswa yang kurang sehat akan mengalami kesulitan belajar karena ia mudah capek, mengantuk, daya konsentrasi hilang dan kurang semangat.

2) Cacat Badan dapat juga menghambat belajar. Termasuk cacat badan misalnya: setengah buta, setengah tuli, gangguan bicara, dan lain-lainnya. Siswa yang kurang pendengarannya atau setengah tuli meskipun ditolong dengan alat-alat khusus, maka tetap saja akan berbeda hasilnya dibanding denagn anak $\square$ anak yang normal. Dengan demikian, seseorang yang belajar 
selain membutuhkan kondisi jasmani yang sehat juga sangat membutuhkan keadaan indera yang normal. Karena keadaan keduanya ini sangat berpengaruh dalam proses belajarnya.

\section{b. Faktor Psikologis}

Faktor yang berhubungan dengan rohaniah. Termasuk dalam faktor ini ialah: Intelligensi, Bakat, Minat, Motivasi, Kesehatan Mental dan Emosi.

1) Kurangnya kemampuan dasar intelligensi siswa

Intelligensi menunjukkan kepada bagaimana cara individu bertingkah laku, cara individu bertindak yaitu cepat atau lambatnya individu di dalam memecahkan masalah yang dihadapi. Dengan demikian, siswa yang mempunyai tingkat kecerdasan diatas rata-rata akan lebih mudah berhasil dalam kegiatan belajar, dan sebaliknya jika siswa memiliki tingkat kecerdasan di bawah rata-rata maka ia akan banyak mengalami kesulitan dalam belajarnya, karena ia akan selalu tertinggal dengan teman-temannya. ketidakberfungsian otak (the brain dysfunction) merupakan penyebab utama (the root of) dari hendaya kesulitan belajar ${ }^{11}$.

2) Tidak ada bakat dalam belajar

Bakat adalah potensi/kecakapan dasar yang dibawa sejak lahir. Setiap individu mempunyai bakat yang berbeda-beda. Seseorang yang berbakat musik mungkin dibanding bidang lain ketinggalan. Seorang yang berbakat di bidang tekhnik tetapi dibidang olah raga lemah. Jadi apabila seorang siswa harus mempelajari bahan yang lain dari bakatnya maka siswa tersebut akan mengalami kesulitan belajar, misalnya: cepat bosan, mudah putus asa, tidak senang dan lain-lain. Begitu juga sebaliknya jika seorang siswa mempelajari suatu bahan yang disenangi dan sesuai dengan bakatnya maka siswa tersebut akan mengalami kemudahan dalam belajar.

3) Kurangnya minat terhadap situasi belajar

${ }^{11}$ Ghufron, M.N \& Rini Risnawati. 2015. Kesulitan Belajar Pada Anak: identifitasi Faktor yang Berperan. Jurnal Elementary. 3(2): 297-311 
84 | Belajea: Jurnal Pendidikan Islam, Vol. 5, No. 01, 2020

Belajar dengan minat akan lebih baik daripada belajar tanpa minat, minat timbul apabila individu tertarik kepada sesuatu karena sesuai dengan kebutuhannya atau merasakan bahwa sesuatu yang akan dipelajari dirasa bermakna bagi dirinya.Adanya minat yang dianggap menentukan sukses tidaknya siswa dalam proses belajar mengajar, karena dengan adanya minat siswa dapat meningkatkan semangat dan membawa rasa senang siswa pada suatu mata pelajaran. Dan sebaliknya dengan kurangnya minat siswa dalam pelajaran akan menyebabkan kurangnya perhatian dan usaha belajar, sehingga menghambat proses belajar atau siswa akan mengalamikesulitan dalam belajarnya.

4) Kurangnya motivasi dalam belajar

Motivasi merupakan pemberian dorongan atau semangatsehingga dapat menimbulkan minat, perhatian dan kemauan siswa dalam belajar. Motivasi merupakan dorongan yang timbul pada diri seseorang yang entah disadari atau tidak untuk melakukan sesuatu tindakan dengan tujuan tertentu ${ }^{12}$. Maka siswa yang memiliki motivasi belajar yang tingi, akan mempermudahnya dalam proses belajar mengajaSebaliknya siswa yang tanpa adanya motivasi dalam belajar, maka akan banyak mengalami kesulitan dalam belajarnya karena motivasi merupakan faktor pendorong dalam belajar.

\section{5) Faktor kesehatan mental dan emosi}

Kesehatan mental dan ketenangan emosi akan menimbulkan hasil belajar yang baik. Dengan demikian, adanya mental dan emosi yang kurang sehat akan mempengaruhi hasil belajar siswa, karena hubungan antara kesehatan mental belajar adalah timbal balik, yang mana kesehatan mental dan emosi akan menimbulkan hasil belajar yang baik.

Seorang guru haruslah memiliki kemampuan dalam mengajar, membimbing dan membina peserta didiknya dalam kegiatan pembelajaran ${ }^{13}$. Upaya guru untuk mengatasi kesulitan belajar Mata Pelajaran pendidikan Agama Islam,Pendidikan dasar jelas berbeda dengan sekolah dasar. Sekolah

\footnotetext{
${ }^{12}$ Subini, N. 2011. Mengatasi Kesulitan Belajar Pada Anak. Perpustakaan. Nasional: Jakarta

13 Abudin Nata, Perspektif Islam tentang Strategi Pembelajaran (Jakarta: Kencana, 2009), hlm. 315
} 
dasar adalah pendidikan formal jenjang terendah, sedangkan pendidikan dasar merupakan pembekalan umum dasar bagi warga negara untuk berpartisipasi dalam hidup sosial, ekonomi, politik, budaya dan hidup keagamaan secara baik. Karena itu, jika pendidikan sebagai upaya menumbuhkan kreativitas peserta didik, memperkaya khazanah budaya manusia, dan menyiapkan tenaga kerja yang produktif. Setiap siswa yang belajar pasti ingin mencapai keberhasilan yang optimal. Maka dari itu berbagai faktor yang dapat menghambat baik faktor yang dari luar maupun dari dalam diri siswa harus dapat teratasi.

Berbagai macam cara mengatasi kesulitan belajar pendidikan agama Islam: 1. Cara mengatasi kesulitan belajar yang berasal dari diri siswa. Antara lain: a) Menjaga kesehatan badan, karena kesehatan dapat menunjang kemampuan belajar dan siswa akan mudah menangkap pelajaran yang dipelajarinya.b) Membangkitkan minat pada diri sendiri dalam setiap belajar dan berusaha mengetahui tujuan belajar secara jelas. Tanpa adanya minat dan tujuan dalam belajar maka hasilnya tidak akan dapat dicapai secara maksimal. Seorang siswa dapat membangkitkan minat belajarnya misalnya dengan menghubungkan pelajaran dengan hal-hal yang menarik dalam kesehariannya, sehingga menjadi menarik untuk dipelajari pelajaran tersebut. Memupuk bakat yang dimilikinya. Bila anak mempunyai bakat dan dia aktif mengikutinya, maka anak akan lebih mudah dalam memecahkan masalah khususnya masalah pelajaran. c) Mendorong dan memotivasi diri untuk belajar. "Motivasi adalah penting bagi proses belajar, karena motivasi menggerakkan organisme, mengarahkan tindakan, serta memilih tujuan belajar yang dirasa paling berguna bagi kehidupan individu". Karena belajar tanpa adanya motivasi sulit untuk mencapai keberhasilan yang semaksimal mungkin. d) Dapat mengatur waktu belajar, istirahat dan kegiatan lainnya. Dengan mengatur waktu seseorang dapat membiasakan disiplin diri dalam segala hal. e) Berusaha memperhatikan dan memusatkan pikiran pada saat pelajaran berlangsung. f) Siswa mempunyai buku literatur-literatur yang dapat menunjangnya dalam belajar. Karena dengan tersedianya literatur siswa akan mudah untuk memecahkan berbagai kesulitan dalam belajarnya. g) Siswa mempunyai tempat belajar sendiri.

Cara mengatasi kesulitan belajar yang berasal dari luar diri siswa. Antara lain: 1. Mengatasi kesulitan belajar dari faktor lembaga sekolah. Solusi kesulitan belajar yang dilakukan oleh lembaga sekolah berupa melengkapi sarana dan prasarana sekolah untuk memperlancar jalannya kegiatan belajar- 
mengajar di sekolah. Antara lain: a. Penataan ruang kelas dalam tata ruang kelas, panjang kelas hendaknya jangan lebih dari delapan atau sembilan bangku sehingga siswa yang duduk di belakang masih bisa membaca tulisan di papan tulis dan mendengarkan suara guru dengan baik. b. Peralatan pengajaran Kelengkapan alat pengajaran juga mempunyai penagruh yang besar pada keberhasilan proses belajar mengajar. Sebaliknya dengan kurangnya alat-alat pengajaran menyebabkan timbulnya kesulitan belajar, untuk itu demi tercapainya tujuan belajar maka alat pengajaran juga harus dilengkap. 2. Cara menanggulangi kesulitan belajar dari faktor keluarga : a. Mengatasi kekacauan rumah tangga Kekacauan rumah tangga dapat mengganggu konsentarsi belajar anak sehingga menimbulkan kesulitan belajar. Oleh karena itu setiap anggota keluarga harus dapat mengatasi atau mencegah timbulnya kekacauan rumah tangga. b. Perhatian orang tua, faktor orang tua ini merupakan salah satu faktor yang memiliki pengaruh cukup besar terhadap perkembangan siswa. Orang tua adalah lembaga pendidikan yang pertama dan utama ${ }^{14}$. c. Memenuhi perlengkapan belajar Tanpa perlengkapan belajar akan menimbulkan sulit dalam belajar bagi anak. Untuk mengatasinya orang tua harus memperhatikan kebutuhan-kebutuhan belajar anak.d. Keadaan ekonomi keluarga dengan perekonomian yang baik maka akan dapat memenuhi kebutuhan belajar anak, sehingga orang tua harus berusaha memenuhi perekonomian keluarga, disamping itu anak juga harus membantu dengan jalan memenfaatkan alat belajar dengan baik dan tidak menghambur-hamburkan uang.

\title{
C. Langkah-Langkah Mengatasi Kesulitan Belajar
}

Upaya untuk membantu kesulitan belajar hanya dapat dilakukan oleh guru jika faktor penyebab kesulitan mampu diidentifikasi dengan baik ${ }^{15}$. Langkah-langkah dalam pemecahan kesulitan belajar meliputi ${ }^{16}$ :

a) Memperkirakan kemungkinan bantuan

\author{
Jakarta. \\ ${ }^{15}$ Ixganda \& Suwahyo. 2015. Analisis Deskriptif Faktor Penyebab Kesulitan Belajar \\ Pada Mata Pelajaran Chassis Dan Pemindah Daya Siswa Kelas Xi Program Keahlian Teknik \\ Kendaraan Ringan. Jurnal Pendidikan Teknik Mesin. 15(2): 103-108 \\ ${ }^{16}$ Mulyadi. 2010. Diagnosis Kesulitan Belajar \& Bimbingan Terhadap Kesulitan \\ Belajar Khusus. Yogyakarta: Nuha Litera.
}

${ }^{14}$ Slameto. 2013. Belajar dan FaktorFaktor Yang Mempengaruhinya. Rineka Cipta: 
Kalau letak kesulitan yang dialami siswa sudah dipahami baik jenis dan sifat kesulitan dengan berbagai macam latar belakangnya.

b) Menetapkan kemungkinan cara mengatasi

Dalam langkah ini perlu diadakan dari rapat staf bimbingan dan konseling jika diperlukan. Setelah hal itu dilaksanakan maka perlu disusun suatu rencana yang berisi tentang beberapa alternatif yang mungkin dilakukan untuk mengatasi kesulitan yang dialami siswa.

c) Tindak lanjut

Tindak lanjut adalah kegiatan melakukan pengajaran remidial (Remidial Teaching) yang diperkirakan tepat dalam membantu siswa yang mengalami kesulitan belajar.

Sebelum melakukan langkah-langkah mengatasi kesulitan belajar, guru sebaiknya melakukan diagnosis kesulitan siswa terlebih dahulu. Untuk melaksanakan kegiatan diagnosis kesulitan belajar harus ditempuh beberapa tahapan kegiatan. Tahapan tersebut meliputi: 1) Mengidentifikasi siswa yang diperkirakan mengalami kesulitan belajar; 2) Melokalisasikan kesulitan belajar; 3) Menentukan faktor penyebab kesulitan belajar; 4) Memperkirakan alternatif bantuan; 5) Menetapkan kemungkinan cara mengatasinya; dan 6) Tindak lanjut $^{17}$

\section{Strategi Guru dalam Mengatasi Kesulitan Belajar PAI}

Strategi pembelajaran dapat diartikan sebagai cara guru dalam mengolah pembelajaran agar dapat mencapai tujuan pembelajaran secara optimal. Strategi pembelajaran merupakan pola umum rentetan kegiatan yang harus dilakukan untuk mencapai tujuan pembelajaran ${ }^{18}$. Strategi dalam pembelajaran adalah sebuah susunan yang disusun oleh pendidik atau rencana dalam proses pembelajaran yang bertujuan menjadi acuan untuk membantu para siswa dalam

${ }^{17}$ Warkitri, dkk, Penilaian Pencapaian Hasil Belajar, (Jakarta: Universitas Terbuka, 1998), h. 8.

18 Sanjaya, Wina. 2009. Kurikulum dan Pembelajaran: Teori dan Praktik pengembangan KTSP. Jakarta; Kencana. 
88 | Belajea: Jurnal Pendidikan Islam, Vol. 5, No. 01, 2020

mencapai, mengukur dan menilai tingkat kompetensi, kecakapan dan kecerdasan siswa dalam pembelajaran ${ }^{19}$.

Usaha yang dapat di upayakan guru untuk mengatasi kesulitan belajar yaitu mengidentifikasi kesulitan belajar sisiwa dan mencari informasi tentang hasil belajar, absesnsi kehadiran dan permasalahan belajarnya. Kemudian mendiagnosis kesulitan belajar yang dialami siswa. Guru membandingkan hasil belajar siswa, dan mengidentifikasi hasil belajar degan batas minimal perolehan skor. Setelah itu, guru memberikan bantuan bimbingan dengan siswa yang mengalami kesulitan belajar. Strategi yang dilakukan dengan menggunakan metode belajar variasi, bentuk bimbingan belajar kelompok, bimbingan belajar individual, pengajaran remedial, dan pemberian bimbingan secara pribadi. Cara mengatasi Hasil artikel ini diperoleh bahwa hasil menunjukan bahwa : (1)Memilih metode pembelajaran PAI secara tepat, sehingga siswa tidak bosan dan jenuh terhadap mata pelajaran PAI khususnya membaca dan menghafal AL-Qur'an. (2) Pengunaan media yang bervariasi baik itu bersumber dari media cetak, elektronik dan sebagainya guna menunjang proses pembelajaran. (3) Selalu memberikan motivasi kepada siswanya setelah selesai kegiatan pembelajaran dan memperkuat semangat di jiwanya sehingga siswa tersebut senang dengan guru tersebut dan otaknya menjadi mudah menerima pelajaran.

Guru dituntut untuk melancarkan proses pembelajaran dengan baik. Setiap guru harus mempunyai strategi pembelajaran, agar setiap peserta didik mampu memahami dan mengerti yang di sampaikan oleh guru. Dalam hal ini, guru dapat mengatasi kesulitan belajar siswa dalam pelajaran PAI antara lain dengan memfasilitasi siswa dalam proses pembelajaran. Guru sebagai fasilitator dan sebagai pembimbing siswa, harus memberikan mootivasi kepada siswa yang sulit belajar. Misalnya dengan menanyakan hal-hal yang kurang dipahami siswa, menanyakan materi yang belum jelas, memberikan petujuk kepada siswa mengenai pelajar yang sedang dipelajari, dan guru menerapkan pembelajaran dengan model pembelajaran yang variatif. Setiap guru harus mampu menguasai

${ }^{19}$ Jihad, Salimul \& Suaeb, M. (2017). Strategi guru dalam mengatasi kesulitan belajar siswa dalam pelajaran mufrodat kelas VI MI NW Dasan Agung Mataram Tahun Pelajaran 2016/2017. el-Tsaqâfah. 17(1): 96-118 
berbagai metode pembelajaran dan memahami situasi belajar-mengajar di dalam maupun di luar kelas ${ }^{20}$.

Strategi yang dilakukan guru untuk menghadapi kesulitan belajar peserta didik yakni: (1) memilih dan merencanakan strategi yang akan digunakan guru untuk mengatasi kesulitan belajar peserta didik, (2) memilih dan merencanakan pendekatan belajar mengajar yang sesuai dengan kondisi peserta didik, dan (3) memilih dan menetapkan metode serta teknik mengajar yang dianggap paling efektif $^{21}$.

\section{Kesimpulan}

Berdasarkan hasil pembahasan di atas dapat disimpulkan bahwa bentuk kesulitan belajar siswa yang muncul dalam pembelajaran Pendidikan Agama Islam materi adalah memilih metode pembelajaran PAI secara tepat, sehingga siswa tidak mengalami kesulitan belajar terhadap mata pelajaran PAI khususnya membaca dan menghafal AL-Qur'an, dan pengunaan media yang bervariasi baik itu bersumber dari media cetak, elektronik dan sebagainya guna menunjang proses pembelajaran.

Faktor penyebab mengalami Kesulitan belajar PAI yaitu: Guru kurang menggunakan metode yang bervariasi, faktor penyebab dari orang tua, kurangnya motivasi terhadap peserta didik. Terdapat dua faktor penyebab kesulitan PAI yaitu faktor dari siswa sendiri (interm) dan faktor dari luar (ekesterm). Upaya untuk mengatasi kesulitan belajar ada dua cara yaitu upaya dari pihak siswa sendiri dengan berusaha mengoptimalkan kemampuan yang dimiliki dengan jalan belajar yang sungguh-sungguh atau belajar kelompok, mencapai cita-cita, serta berusaha menerapkan Pendidikan Agama Islam dalam kehidupan sehari-hari.

${ }^{20}$ Munirah. 2018. Peranan Guru dalam Mengatasi Kesulitan Belajar Siswa. Tarbawi: Jurnal Pendidikan Agama Ilsam. 3(2): 111-127

${ }^{21}$ Chan, Faizal., Pamela, I.S., Sinaga. I.S., Mesariani, Oktarina,R \& Julianti.M. 2019. Strategi Guru Dalam Mengatasi Kesulitan Belajar Di Sekolah Dasar. AULADUNA: Jurnal Pendidikan Dasar Islam. 6 (2): 173-182 
90 | Belajea: Jurnal Pendidikan Islam, Vol. 5, No. 01, 2020

Sedangkan upaya dari luar (eksterm) di antaranya dari pihak guru dengan meningkatkan pengetahuan dengan mengikuti pelatihan, menggunakan metode dan media pembelajaran dalam kegiatan pembelajaran PAI, guru menciptakan suasana yang dapat membuat siswa senang, memenuhi sarana dan prasarana pendidikan agama, memberikan bimbingan kepada siswa-siswi yang mengalami kesulitan belajar pendidikan agama, serta dari pihak keluarga dengan cara menciptakan situasi keluarga yang harmonis, berusaha lebih memperhatikan anak, khususnya dalam hal belajar agama Islam.

\section{Bibliografhy}

An-Nahlawi, Abdurrahman, 1989. Ushulut Tarbiyatil Ilmiyah wa Asalibuba, Ter. Hery Noer Aly. Bandung: CV. Diponegoro, Abudin Nata. 2009. Perspektif Islam tentang Strategi Pembelajaran. Jakarta: Kencana.

Chan, Faizal., Pamela, I.S., Sinaga. I.S., Mesariani, Oktarina,R \& Julianti.M. 2019. Strategi Guru Dalam Mengatasi Kesulitan Belajar Di Sekolah Dasar. AULADUNA: Jurnal Pendidikan Dasar Islam. 6.

Ghufron, M.N \& Rini Risnawati. 2015. Kesulitan Belajar Pada Anak: identifitasi Faktor yang Berperan. Jurnal Elementary. 3.

Ismail. 2016. Diagnosis Kesulitan Belajar Siswa dalam Pembelajaran Aktif di Sekolah. Jurnal Edukasi. 2.

Ixganda \& Suwahyo. 2015. Analisis Deskriptif Faktor Penyebab Kesulitan Belajar Pada Mata Pelajaran Chassis Dan Pemindah Daya Siswa Kelas Xi Program Keahlian Teknik Kendaraan Ringan. Jurnal Pendidikan Teknik. Mesin. 15.

Jihad, Salimul \& Suaeb, M. 2017. Strategi guru dalam mengatasi kesulitan belajar siswa dalam pelajaran mufrodat kelas VI MI NW Dasan Agung Mataram Tahun Pelajaran 2016/2017. el-Tsaqâfah. 17.

Munirah. 2018. Peranan Guru dalam Mengatasi Kesulitan Belajar Siswa. Tarbawi: Jurnal Pendidikan Agama Ilsam. 3. 
Siti Nusroh, dkk: Analisis Kesulita Belajar Serta Cara Mengatasinya

Muntari. 2015. Upaya Guru Mengatasi Kesulitan Belajar Siswa Bidang Studi Pendidikan Agama Islam Di SD Mujahidin 2 Surabaya . Tarus: Jurnal Pendidikan Islam. 4 .

Mulyadi. 2010. Diagnosis Kesulitan Belajar \& Bimbingan Terbadap Kesulitan Belajar Khusus. Yogyakarta: Nuha Litera.

Pane, Aprida. 2017. Belajar dan Pembelajaran. Jurnal Kajian Ilmu-Ilmu Keislaman. 3.

Ramayulis. 2001. Metodologi Pengajaran Agama Islam, Jakarta: Radar Jaya Offset,

Rooljakers, A.D. 1989. Mengajar dengan Sukses, Jakarta: Gramedia

Slameto. 2013. Belajar dan FaktorFaktor Yang Mempengaruhinya. Rineka Cipta: Jakarta.

Subini, N. 2011. Mengatasi Kesulitan Belajar Pada Anak. Perpustakaan. Nasional: Jakarta

Sudarwan Danim. 2010. Perkembangan Peserta Didik. Bandung: Alfabeta

Susanti, R. D. 2018. Strategi Guru Kelas Dalam Mengatasi Kesulitan Belajar Akademik Siswa Dalam Pembelajaran Di Sekolah Dasar. KONSELING EDUKASI Journal of Guidance and Counseling, 2.

Suryani, Yulinda Erma. 2010. Kesulitan Belajar. Jurnal Penelitian Magistra. Magistra Th. XXII. No. 73.

Warkitri, dkk. 1998. Penilaian Pencapaian Hasil Belajar. Jakarta: Universitas Terbuka. 
92 | Belajea: Jurnal Pendidikan Islam, Vol. 5, No. 01, 2020 